\title{
Effect of ascorbic and salicylic acids on growth and flowering of Gazania cv. Frosty Kiss Mixed
}

\author{
Abdul Kareem A.J. Mohammad Saeed (1)
}

University of Diyala, College of Agriculture, Department of Horticulture and Landscape Architecture, Iraq.

\begin{abstract}
An experiment was conducted during the season 2018-2019 in the lath house to study the effect of foliar spray with Ascorbic Acid (AsA) and Salicylic Acid (SA) on vegetative and flowering growth traits of Gazania (Gazania rigens L.) cv. Frosty Kiss Mixed. The experiment was designed as a factorial experiment $(3 \times 3)$ in Randomized Complete Blocks Design (RCBD) with three replicates. Plants were sprayed with concentrations of 0,100 , and $200 \mathrm{mg} \mathrm{L}^{-1}$ of AsA, and 0,150 and $300 \mathrm{mg} \mathrm{L}^{-1}$ of SA. Foliar spray with $200 \mathrm{mg} \mathrm{L}^{-1}$ of AsA was superior on increasing number of leaves (40.00), number of suckers (9.22), leaf area $\left(2174.09 \mathrm{~cm}^{2}\right)$, leaves dry weight (6.36 g), number of flowers (5.64), early of flowering date (97.22 days), flower fresh and dry weight (4.78 g) (0.51 g) respectively, while spray with a concentration of $100 \mathrm{mg} \mathrm{L}^{-1}$ led to increase flower diameter $(6.37 \mathrm{~cm})$ and flowering duration $(10.85$ days). Foliar spray with SA improved all vegetative and flowering traits. Treatment of $300 \mathrm{mg} \mathrm{L}^{-1}$ was the most significant effect in increasing number of leaves (39.56), leaf area $\left(2182.06 \mathrm{~cm}^{2}\right)$, leaves fresh weight (43.93 g), number of flowers (5.83), flower diameter $(6.31 \mathrm{~cm})$, early of flowering date $(98.07$ days), and flower dry weight $(0.50 \mathrm{~g})$. The interaction effect between the studied factors was significant in all studied traits. Treatment of AsA200 $\times$ SA150 was the most effective and gave the best results in terms of number of suckers (9.11), dry weight of leaves (6.49 g), number of flowers (5.87), flower diameter (6.44 cm), flowering date (96.98 days), flowering duration (10.89 days).
\end{abstract}

Keywords: ascorbic acid, floral growth, foliar spray, Gazania rigens L., salicylic acid, vegetative growth.

\section{Resumo}

Efeito dos ácidos ascórbico e salićlico no crescimento e floração de Gazania cv. Frosty Kiss Mixed

O experimento foi conduzido no período 2018-2019 em ripado para estudar o efeito da aspersão foliar com ácido ascórbico (AsA) e ácido salicílico (SA) sobre as características de crescimento vegetativo e florescimento de Gazania (Gazania rigens L.) cv. Frosty Kiss Mixed. O experimento foi delineado como fatorial $(3 \times 3)$ em design de blocos completamente casualizados $(\mathrm{RCBD})$ com três repetições. As plantas foram pulverizadas com concentrações de 0,100 e $200 \mathrm{mg} \mathrm{l}^{-1}$ de AsA e 0,150 e $300 \mathrm{mg} \mathrm{l}^{-1} \mathrm{de} \mathrm{SA}^{\text {A }}$ pulverização foliar com $200 \mathrm{mg} \mathrm{l}^{-1}$ de AsA foi superior no número de folhas (40,00), número de brotos $(9,22)$, área foliar $(2174,09$ $\left.\mathrm{cm}^{2}\right)$, peso seco das folhas $(6,36 \mathrm{~g})$, número de flores $(5,64)$, no início da data da floração $(97,22$ dias), peso fresco e seco da inflorescência ( $4,78 \mathrm{~g} \mathrm{e} 0,51 \mathrm{~g}$, respectivamente) enquanto a pulverização com a concentração de $100 \mathrm{mg} \mathrm{l}^{-1}$ induziu ao aumento do diâmetro da flor $(6,37 \mathrm{~cm})$ e da duração da floração (10,85 dias). A pulverização foliar com SA melhorou todas as características vegetativas e florais. O tratamento de $300 \mathrm{mg} \mathrm{l}^{-1}$ foi o efeito mais significativo no aumento do número de folhas $(39,56)$, área foliar $\left(2182,06 \mathrm{~cm}^{2}\right)$, peso fresco das folhas $(43,93 \mathrm{~g})$, número de flores $(5,83)$, diâmetro das flores $(6,31 \mathrm{~cm})$, no início da data da floração ( 98,07 dias) e peso seco da inflorescência $(0,50 \mathrm{~g})$. O efeito da interação entre os fatores estudados foi significativo em todas as características estudadas. O tratamento de AsA200 $\times$ SA150 foi o mais eficaz e proporcionou os melhores resultados em termos de número de brotos $(9,11)$, peso seco das folhas $(6,49 \mathrm{~g})$, número de flores $(5,87)$, diâmetro da flor $(6,44 \mathrm{~cm})$, data da floração $(96,98$ dias), duração da floração (10,89 dias).

Palavras-chave: ácido ascórbico, crescimento floral, pulverização foliar, Gazania rigens L., ácido salicílico, crescimento vegetativo.

"Corresponding author: kareemmohammad56@yahoo.com 


\section{Introduction}

Gazania (Gazania rigens) (syn. G. splendens), sometimes called treasure flower, is a species and flowering plant in the family Asteraceae. It is widely cultivated as an ornamental garden plant. The well-known garden plant Gazania rigens originates in South Africa. The petals are usually orange, yellow or white, but sometimes bronze or pink. At the base they are often brown forming an attractive ring at the center. The flowers close at night and open again with first rays of the sun. Gazania performs well in borders, rock gardens and in pots (Sardoei and Shahdadneghad, 2014). It is being seeds easily and has attractive flowers with a long flowering period, from middle spring to autumn (Pittenger et al., 2001).

Improvement of plant growth via bioestimulants such as amino acids, organic acids and other mineral and organic compounds, in absence of fertilizer application, have got significant attention in recent years (Souri and Hatamian, 2019). It has been shown that application of growth bioestimulants significantly improved the growth performance of different plant species particularly under variable and stressful environment conditions (Souri and Bakhtiarizade, 2019; Aghaye Noroozlo et al., 2019; Mohammadipor and Souri, 2019).

Ascorbic Acid (AsA) is a small antioxidant molecule, vitamin C (L-ascorbic acid), fulfills essential metabolic functions in the life of animals and plants. L-Ascorbic Acid serves as a cofactor for many enzymes (Arrigoni and Tullio, 2000). AsA functions as a major redox buffer and as a cofactor for enzymes involved in regulating photosynthesis, hormone biosynthesis, and regenerating other antioxidants. AsA regulates cell division and growth and is involved in signal transduction (Ashihara et al., 2013). Previous research, Abdel-Aziz et al. (2006), on Khya senegalensis and Abdel-Aziz et al. (2009) on Gladiolus grandiflora L., indicated that application of AsA significantly increased all growth traits and some chemical components.

Salicylic acid (SA) or ortho-hydroxy benzoic acid and other salicylates are known to affect various physiological and biochemical activities of plants and may play a key role in regulating their growth and productivity and in the responses to environmental stresses (Hayat et al., 2010). Further, its role is evident in seed germination, fruit yield, glycolysis, flowering in thermogenic plants (Klessig and Malamy, 1994), ion uptake and transport (Harper and Balke, 1981), photosynthetic rate, stomatal conductance and transpiration (Khan et al., 2003). SA has been reported to induce flowering in a number of plants. Different plant species including ornamental plant Sinningia speciosa flowered much earlier as compared to the untreated control, when they received an exogenous foliar spray of SA (Martin-Max et al., 2005). The main objective was to investigate the effect of foliar spray with AsA and SA on early flowering and to extend the flowering duration of Gazania rigens L. cv. Frosty Kiss Mixed.

\section{Materials and Methods}

The experiment was carried out in the lath house for the fall season $2018-2019$ at $22 \pm 5^{\circ} \mathrm{C}$ and relative humidity of $40-60 \% \pm 5 \%$. Gazania (Gazania rigens L.) cv. Frosty Kiss Mixed seeds were sown (25/10/2018) in cork plates containing peat moss. One month after germination of seeds homogeneous seedlings were picked up (approximately 15 $\mathrm{cm}$ ) and transferred to $18 \mathrm{~cm}$ pot (one plant.pot ${ }^{-1}$ ) filled with a sandy loam soil. Cultivation soil was analyzed in the laboratory of the Department of Soil and Water Resources /College of Agriculture/University of Diyala, as shown in the Table (1).

Table 1. Some of chemical and physical properties of cultivation soil.

\begin{tabular}{|c|c|c|}
\hline The character & The value & The unit \\
\hline $\mathrm{P}^{\mathrm{H}}(1: 1)$ & 7.17 & - \\
\hline EC (1:1) & 2.38 & $\mathrm{dS} . \mathrm{m}^{-1}$ \\
\hline Soil Separation & & \\
\hline Clay & 100.1 & $\mathrm{~g} . \mathrm{kg}^{-1}$ \\
\hline Silt & 68.1 & $\mathrm{~g} \cdot \mathrm{kg}^{-1}$ \\
\hline Sand & 831.8 & $\mathrm{~g} \cdot \mathrm{kg}^{-1}$ \\
\hline Organic matter & 2.829 & $\%$ \\
\hline Available N & 35.11 & $\mathrm{~g} \cdot \mathrm{kg}^{-1}$ \\
\hline Available P & 4.01 & $\mathrm{~g} \cdot \mathrm{kg}^{-1}$ \\
\hline Available K & 251.241 & $\mathrm{~g} \cdot \mathrm{kg}^{-1}$ \\
\hline
\end{tabular}


Plants were fertilized with chemical fertilizer King Life Fruit (GREEN COMPANY HAS ITALIA SPA- ITALY) consisting of N, P, K $(18 \%-9.5 \%-6 \%)$ with Magnesium (Mg 4\%), Boron (B 2\%), Iron (Fe 0.80\%), Manganese (Mn $0.80 \%$ ), Molybdenum (Mo 0.08\%) and Zinc (Zn 0.80\%), as a foliar application (100 cc per plant) every two weeks throughout $\mathrm{t}$ the experiment period, at a rate of $1 \mathrm{~g} \mathrm{l}^{-1}$ as recommended by the manufacturer. Service operations such as hoeing, weeding and control of insect and disease injuries were conducted whenever needed. Plants were sprayed with Ascorbic Acid (AsA) at concentrations of 0, 100, and $200 \mathrm{mg} \mathrm{L}^{-1}$ (Mazher et al, 2011) symbolized by AsA0, AsA100 and AsA200, respectively, and Salicylic Acid (SA) at concentrations of 0,150 and $300 \mathrm{mg} \mathrm{L}^{-1}$ symbolized by SA0, SA150, and SA300, respectively. The plants were sprayed twice. The first spray was carried out 45 days after transplanting and the second spray after 10 days of the first spray with two days interval between spraying AsA and SA. Tween-20 was added at concentration of $0.1 \%$, as a surfactant compound, plants sprayed with concentrations used until complete wetting by a 2 liters capacity hand sprayer. The experiment was carried out as a factorial experiment $(3 \times 3$ factors $)$ according to the Randomized Complete Block Design (RCBD) with three replicates. Each treatment had 6 plants per replicate. The data were analyzed according to the statistical program (SAS, 2002). Means were compared using Less Significant Difference Test (LSDT) $(\mathrm{P} \leq 0.05)$. The Experimental measures included the vegetative growth qualities like number of leaves, number of suckers, leaf area $\left(\mathrm{cm}^{2}\right)$, fresh and dry weight of leaves $(\mathrm{g})$, and floral growth qualities like number of flowers, flower diameter (cm), flowering date (days) (number of days required for first flower emergence), flowering duration (days), fresh and dry weight of flower $(\mathrm{g})$.

\section{Results}

\section{Vegetative growth traits}

Data on various vegetative growth parameters, i.e. number of leaves, number of suckers, leaf area, fresh and dry weight of leaves, are tabulated in table $(2-\mathrm{A}, \mathrm{B}, \mathrm{C})$. Spraying with AsA resulted in a significant increase in number of leaves. Treatment of AsA200 gave the highest number of leaves (40.00). However, it was on par with AsA100 which gave 39.11 leaves per plant. Treatment of
AsA200 resulted in a significant increase in number of suckers (9.22). However, it was on par with AsA100 which gave 7.89. Treatment of AsA200 gave the highest leaf area $\left(2174.09 \mathrm{~cm}^{2}\right)$. However, it was on par with AsA100 which gave $2155.68 \mathrm{~cm}^{2}$. Ascorbic acid foliar spray showed no significant difference in Fresh weight of leaves, while it resulted in a significant increase in dry weight of leaves $(6.36 \mathrm{~g})$ compared to control treatment $(6.12 \mathrm{~g})$.

The results showed that treatment of SA300 led to a significant increase in number of leaves (39.56), while treatment of SA150 resulted in a significant increase in number of suckers (9.00). It is noted that spraying with SA led to a significant increase in leaf area, and treatment of SA300 recorded the highest leaf area $\left(2182.06 \mathrm{~cm}^{2}\right)$. However, it was on par with SA150 which recorded $2144.58 \mathrm{~cm}^{2}$. It was observed that treatment of SA150 resulted in a significant increase in fresh weight of leaves reached 43.99. However, it was on par with SA300 which recorded $43.93 \mathrm{~g}$. Treatment of SA150 resulted in a significant increase in dry weight of leaves (6.62 g) compared to other treatments.

Interaction of AsA and SA showed that there was a significant difference in all studied vegetative growth traits. Treatment of AsA200×SA150 was the most effective in increasing number of suckers and dry weight of leaves and recorded 9.11 and $6.49 \mathrm{~g}$, respectively. Data indicate that treatment of AsA200 $\times$ SA0 was significantly superior to other treatments in increasing leaf area $\left(2224.86 \mathrm{~cm}^{2}\right)$. Treatment of AsA $0 \times \mathrm{SA} 300$ led to a significant increase in fresh weight of leaves $(43.80 \mathrm{~g})$.

\section{Flowering traits}

Data on various flowering parameters, i.e. number of flowers, flower diameter, flowering date (number of days required for first flower emergence), flowering duration, fresh and dry weight of flower, are tabulated in table (3 A, B, C). Data showed that treatment of AsA200 led to a significant increase in number of flowers (5.64), early in the flowering date (number of days required for first flower emergence) (97.22 days), however, it was on par with AsA100 which recorded 98.40 days. Treatment of AsA200 led to a significant increase in fresh and dry weight of flower reached 4.78 and $0.51 \mathrm{~g}$, respectively, while treatment of AsA100 gave the best results in terms of flower diameter $(6.37 \mathrm{~cm})$ and flowering duration (10.85 days) compared to control treatment. 
Table 2. Effect of ascorbic and salicylic acids on vegetative growth traits of Gazania (Gazania rigens L.) cv. Frosty Kiss Mixed.

\begin{tabular}{|c|c|c|c|c|c|c|}
\hline \multicolumn{7}{|c|}{ A- Effect of AsA } \\
\hline \multicolumn{2}{|c|}{$\begin{array}{l}\text { Characters } \\
\text { Treatments }\end{array}$} & $\begin{array}{c}\text { Number of } \\
\text { leaves }\end{array}$ & $\begin{array}{c}\text { Number of } \\
\text { suckers }\end{array}$ & $\begin{array}{c}\text { leaf area per } \\
\text { plant }\left(\mathrm{cm}^{2}\right)\end{array}$ & $\begin{array}{l}\text { Fresh weight of } \\
\text { leaves (g) }\end{array}$ & $\begin{array}{c}\text { Dry weight of } \\
\text { leaves (g) }\end{array}$ \\
\hline \multicolumn{2}{|c|}{ AsA0 } & 38.44 & 7.67 & 2125.64 & 43.33 & 6.12 \\
\hline \multicolumn{2}{|c|}{$\operatorname{AsA100}$} & 39.11 & 7.89 & 2155.68 & 43.50 & 6.16 \\
\hline \multicolumn{2}{|c|}{ AsA200 } & 40.00 & 9.22 & 2174.09 & 43.58 & 6.36 \\
\hline \multicolumn{2}{|c|}{ L.S.D $(p \leq 0.05)$} & 0.364 & 1.335 & 41.241 & n.s. & 0.171 \\
\hline \multicolumn{7}{|c|}{ B- Effect of SA } \\
\hline \multicolumn{2}{|c|}{ SA0 } & 38.78 & 7.78 & 2128.78 & 42.57 & 5.70 \\
\hline \multicolumn{2}{|c|}{ SA150 } & 39.22 & 9.00 & 2144.58 & 43.99 & 6.62 \\
\hline \multicolumn{2}{|c|}{ SA300 } & 39.56 & 8.00 & 2182.06 & 43.93 & 6.31 \\
\hline \multicolumn{2}{|c|}{ L.S.D $(p \leq 0.05)$} & 0.364 & n.s. & 41.241 & 0.263 & 0.171 \\
\hline \multicolumn{7}{|c|}{ C- Effect of $A s A \times S A$} \\
\hline \multirow{3}{*}{ AsA0 } & SA0 & 36.67 & 7.73 & 2100.83 & 42.95 & 5.91 \\
\hline & SA150 & 39.33 & 8.34 & 2145.64 & 43.66 & 6.37 \\
\hline & SA300 & 40.33 & 7.84 & 2139.86 & 43.79 & 6.22 \\
\hline \multirow{3}{*}{ AsA100 } & SA0 & 37.67 & 7.84 & 2141.36 & 43.08 & 5.93 \\
\hline & SA150 & 39.00 & 8.45 & 2125.09 & 43.79 & 6.39 \\
\hline & SA300 & 41.00 & 7.95 & 2167.28 & 43.76 & 6.24 \\
\hline \multirow{3}{*}{$\operatorname{AsA200}$} & SA0 & 39.67 & 8.50 & 2215.86 & 43.08 & 6.03 \\
\hline & SA150 & 37.00 & 9.11 & 2106.19 & 43.80 & 6.49 \\
\hline & SA300 & 42.00 & 8.61 & 2224.13 & 43.76 & 6.34 \\
\hline \multicolumn{2}{|c|}{ L.S.D $(P \leq 0.05)$} & 2.223 & 1.101 & 113.023 & 0.701 & 0.284 \\
\hline
\end{tabular}

Treatment of SA300 gave the best results in terms of number of flowers $(5.83)$, flower diameter $(6.31 \mathrm{~cm})$, flowering date (98.07 days), however, it was on par with SA150 which recorded 98.63 days. Treatment of SA300 led to a significant increase in dry weight of flower $(0.50$ $\mathrm{g}$ ), while treatment of SA150 gave the best results in terms of flowering duration (10.96 days) compared to control treatment.
Interaction of AsA and SA showed that there was a significant difference in all studied floral traits. Treatment of AsA200 $\times$ SA150 was the most effective and gave the best results in terms of number of flowers (5.87), flower diameter $(6.44 \mathrm{~cm})$, flowering date (96.98 days), flowering duration (10.89 days), while treatment of AsA200 $\times$ SA300 was significantly superior to the rest of treatments in increasing fresh and dry weight of flower reached 4.87 and $0.51 \mathrm{~g}$, respectively. 
Table 3. Effect of ascorbic and salicylic acids on flowering traits of Gazania (Gazania rigens L.) cv. Frosty Kiss Mixed.

\begin{tabular}{|c|c|c|c|c|c|c|c|}
\hline \multicolumn{8}{|c|}{ A- Effect of AsA } \\
\hline \multicolumn{2}{|c|}{$\begin{array}{l}\text { Characters } \\
\text { Treatments }\end{array}$} & $\begin{array}{l}\text { Number of } \\
\text { flowers }\end{array}$ & $\begin{array}{l}\text { Flower } \\
\text { diameter } \\
(\mathbf{c m})\end{array}$ & $\begin{array}{c}\text { Number } \\
\text { of days to } \\
\text { flowering } \\
\text { (day) }\end{array}$ & $\begin{array}{c}\text { Flowering } \\
\text { duration } \\
\text { (day) }\end{array}$ & $\begin{array}{l}\text { Fresh weight } \\
\text { of flower (g) }\end{array}$ & $\begin{array}{l}\text { Dry weight } \\
\text { of flower (g) }\end{array}$ \\
\hline \multicolumn{2}{|c|}{ AsA0 } & 4.39 & 5.94 & 108.22 & 9.89 & 4.52 & 0.38 \\
\hline \multicolumn{2}{|c|}{ AsA100 } & 5.49 & 6.37 & 98.40 & 10.85 & 4.71 & 0.49 \\
\hline \multicolumn{2}{|c|}{$\operatorname{AsA200}$} & 5.64 & 6.13 & 97.22 & 10.29 & 4.78 & 0.51 \\
\hline \multicolumn{2}{|c|}{ L.S.D $(p \leq 0.05)$} & 0.013 & 0.178 & 9.011 & 0.660 & $\mathrm{n} . \mathrm{s}$ & 0.063 \\
\hline \multicolumn{8}{|c|}{ B- Effect of SA } \\
\hline \multicolumn{2}{|c|}{ SA0 } & 4.23 & 5.94 & 107.14 & 9.96 & 4.51 & 0.42 \\
\hline \multicolumn{2}{|c|}{ SA150 } & 5.46 & 6.18 & 98.63 & 10.96 & 4.74 & 0.46 \\
\hline \multicolumn{2}{|c|}{ SA300 } & 5.83 & 6.31 & 98.07 & 10.11 & 4.76 & 0.50 \\
\hline \multicolumn{2}{|c|}{ L.S.D $(p \leq 0.05)$} & 0.013 & 0.178 & 9.011 & 0.660 & $\mathrm{n} . \mathrm{s}$ & 0.063 \\
\hline \multicolumn{8}{|c|}{ C- Effect of $\mathbf{A s A} \times \mathbf{S A}$} \\
\hline \multirow{3}{*}{ AsA0 } & SA0 & 4.20 & 6.00 & 118.44 & 9.93 & 4.51 & 0.40 \\
\hline & SA150 & 5.43 & 6.22 & 101.22 & 10.43 & 4.62 & 0.42 \\
\hline & SA300 & 5.53 & 6.33 & 101.78 & 10.00 & 4.65 & 0.44 \\
\hline \multirow{3}{*}{ AsA100 } & SA0 & 4.40 & 6.22 & 106.44 & 9.89 & 4.62 & 0.46 \\
\hline & SA150 & 5.33 & 6.43 & 97.00 & 10.33 & 4.75 & 0.48 \\
\hline & SA300 & 5.63 & 6.28 & 92.44 & 9.66 & 4.75 & 0.50 \\
\hline \multirow{3}{*}{ AsA200 } & SA0 & 4.86 & 6.04 & 99.77 & 10.22 & 4.65 & 0.47 \\
\hline & SA150 & 5.87 & 6.44 & 96.98 & 10.89 & 4.75 & 0.49 \\
\hline & SA300 & 5.77 & 6.22 & 97.44 & 10.20 & 4.87 & 0.51 \\
\hline \multicolumn{2}{|c|}{ L.S.D $(p \leq 0.05)$} & 0.372 & 0.233 & 22.072 & 1.005 & 0.391 & 0.012 \\
\hline
\end{tabular}

\section{Discussion}

Data showed that foliar spray with AsA positively affected some vegetative and floral growth traits of Gazania plant. The improvement of vegetative and floral qualities as a result of spraying with AsA may be due to its role in different functions. It is a cofactor for the enzymes involved in a variety of processes including flavonoids, plant hormone synthesis, and xanthophyll cycle (Tullio and Arrigoni, 2004). Also this increment in vegetative growth may be attributed to the fact that this acid co-regulates the cell division. In this respect Smirnoff (1996) reported that ascorbate has been implicated in regulation of cell division. In this connection, who also pointed out that cell wall ascorbate and cell wall localized ascorbate oxidase has been implicated in control of growth; high ascorbate oxidase activity is associated with rapidly expanding cells. The results could paint in the same direction of Abo Leila and Eid (2011) in gladiolus. It has been shown that the leaf content of AsA is a good indicator of leaf healthy conditions in many plant species 
particularly in vegetable crops (Souri and Hatamian, 2019; Mohammadipour and Souri, 2019). In addition, higher nutrients uptake and their bioavailability to different cell metabolism is generally enhanced under higher AsA content (Souri and hatamian, 2019).

Similarly, the increase in floral characteristics such as number of flowers, flower diameter and dry weight of flower as a result of foliar spray with AsA may be due to the effect of the used material on improving the vegetative growth of Gazania plants, consequently the production and accumulation of the biosynthesizes would be increased, thus more flowers could be initiated and developed on the plant. These results are in harmony with those obtained be (Naglaa et al., 2011) in tuberose. Furthermore, foliar spray with AsA caused early flowering compared to control treatment. These results may be due to that presence of AsA can serve as a source of energy and enhance the synthesis of auxin, organic materials or enzymes (Patil and Lall, 1973 and John et al., 1997) These results agree with those obtained by (Naglaa et al., 2011). Moreover, the increase in the flowering duration by foliar spray with AsA compared to control treatment may be due to that using AsA at optimum concentrations act as scavengers, helping to prevent cell and tissue damage and delay of the flowers senescence (Eman et al., 2012).

Data showed that foliar spray with SA had a positive effect on most vegetative and floral qualities of Gazania. The improvement of vegetative and floral qualities as a result of spraying with SA may be due to the fact that $\mathrm{SA}$ is a phenolic compound that enables plants to survive under challenging soil and environmental situations. SA plays key roles in regulation of various physiological and developmental processes of plants (Souri and Tohidloo, 2019). These positive effects may be due to the role of SA in increasing the plant content of internal hormones such as gibberellin, auxin and cytokinine, thus increasing cell division and elongation and ultimately promoting plant growth and development (Hayat and Ahmed, 2007). There is evidence of a cross-talk between SA and auxin signaling pathways during plant vegetative growth (Rivas-San Vicente and Plascencia, 2011). Improvement of vegetative growth due to foliar spray with SA in this study are in agreement with those obtained by Martin-Mex et al. (2005) on African violet, Hashish et al. (2015) on Calendula officinalis, and Qureshi et al. (2015) on Dianthus caryophyllus. Similarly, data of this study showed that treatment with SA caused increase in number and flower diameter and dry weight of flower. This result may be due to the role of SA in improving vegetative growth and that lead to an increase in the absorption of nutrients, also it promotes photosynthesis in plant that lead to higher carbohydrate biosynthesis (Souri and Tohidloo, 2019) toward higher flower differentiation and inductions. Application of SA can also increase auxin levels and therefore flower growth (Hayat and Ahmed, 2007; Zamani et al., 2011). Improvement of floral growth qualities of Gazania due to foliar spray with SA in this study are in agreement with those obtained by Pacheco et al. (2013) on Calendula officinalis, Sardoei et al. (2014) on Petunia hybrida.
The present study indicating further that foliar spray of both AsA and SA improved vegetative and floral growth qualities of Gazania plant. Such positive increase could be explained by the fact that AsA and SA considered as a bio regulator compounds which in optimum concentration exerted profound influence upon plant growth and production and may be due to the synergetic effect between AsA and SA in increasing plant growth and metabolism.

\section{Conclusions}

From the results of the present study, it can be concluded that foliar spray with AsA and SA, positively affected the vegetative and floral growth qualities of Gazania. Treatment of AsA $200 \times \mathrm{SA} 300$ gave the best results in respect of number of leaves, leaf area, flowering date, fresh and dry weight of flower, while treatment of AsA $200 \times$ SA150 gave the best results in respect of number of suckers, fresh and dry weight of leaves, number and flower diameter, number of days to flowering, and flowering duration.

\section{References}

ABD EL-AZIZ, N.; AZZA A.M. M.; EL.HABBA, E. Effect of foliar spraying with ascorbic acid on growth and chemical constituents of Khya senegalensis grown under salt condition. American-Eurasian Journal of Agricultural \& Environmental Sciences, v.3, p.207-214, 2006.

ABD EL-AZIZ, N.G.; LOBNA, T.T.; IBRAHIM, S.M.M. Some studies on the effect of putrescine, ascorbic acid and thiamine on growth, flowering and some chemical constituents of gladiolus plants at Nubaria. Ozean Journal of Applied Science, v.2, n.2, 169-179, 2009.

ABO LAILA, B.A.; EID, R.A. Improving gladiolus growth, flower keeping quality by using some vitamins application. Journal of American Science, v.7, n.3, 169-174, 2011.

AGHAYE NOROOZLO, Y.; SOURI, M.K.; DELSHAD, M. Effects of soil application of amino acids, ammonium, and nitrate on nutrient accumulation and growth characteristics of sweet basil. Communications in Soil Science and Plant Analysis, v.50, n.22, 2864-2872, 2019. https://doi.org/10.1080/00103624.2019.1689249

ARRIGONI, O.; TULLIO M.C. The role of ascorbic acid in cell metabolism: between gene-directed functions and unpredictable chemical reactions. Journal of Plant Physiology, v.157, n.5, p.481-488, 2000. https://doi. org/10.1016/S0176-1617(00)80102-9

ASHIHARA, H.; RIGANTI, C.; VANIN, A. L-Ascorbic acid: a multifunctional molecule supporting plant growth and development. Scientifica, Article ID, 795964, p.24, 2013. 
EMAN, S.; EL-NAGGAR, H.; OSMAN, A. Effect of nitrogen and diphenylamine on Gladiolus hybrida cv. Sancerre production. Journal of Horticultural Science \& Ornamental Plants, v.4, n.3, p.267-274, 2012.

HARPER, J.R.; BALKE, N.E. Characterization of the inhibition of $\mathrm{K}+$ absorption in oats roots by salicylic acid. Plant Physiology, v.68, p.1349-1353. 1981.

HASHISH, KH.I.; MAZHAR, A.A.M.; ABDEL AZIZA, N.G.; MAHGOUB, M.H. The influence of different levels of foliar-application SA on the flowering and some chemical compositions of Calendula officinalis L. under salinity irrigation. International Journal of ChemTech Research, v.8, n.6, p.890-897, 2015.

HAYAT, Q.; HAYAT., S.; IRFAN, M.; AHMAD, A. Effect of exogenous salicylic acid under changing environment: A review. Environmental and Experimental Botany, v.68, p.14-25, 2010. https://doi.org/10.1016/j. envexpbot.2009.08.005

HAYAT, S.; AHMED A. Salicylic acid: biosynthesis, metabolism and physiological role in plants. Netherland: Springer, 2007. 389p.

JOHN, A.; PAUL, T.; SIDDIQUE, M. Nutritional studies in gladiolus 1: Growth and floral characters. Advances in Plant Sciences, v.10, p.45-49, 1997.

KHAN, W.; PRITHVIRAJ, B.; SMITH, D.L. Photosynthetic responses of corn and soybean to foliar application of salicylates. Journal of Plant Physiology, v.160, p.485492, 2003. https://doi.org/10.1078/0176-1617-00865

KLESSIG, D.F.; MALAMY, J. The salicylic acid signal in plants. Plant Molecular Biology, v.26, p.1439-1458, 1994.

MARTIN-MEX, R.; VILLANUEVA-COUOH， E.; HERRERA-CAMPOS, T.; LARQUE'-SAAVEDRA, A.A. Positive effect of salicylates on the flowering of African violet. Scientia Horticulturae, v.103, p.499-502, 2005. https://doi.org/10.1016/j.scienta.2004.06.020

MAZHER, A.A.M.; SAHAR, M.Z.; MAHMOUD, S.A.; SIAM, H.S. Stimulatory effect of kinetin, ascorbic acid and glutamic acid on growth and chemical constituents of Codiaeum variegatum L. plants. American-Eurasian Journal of Agricultural \& Environmental Sciences, v.10, n.3, p.318-323, 2011.

MOHAMMADIPOUR, N.; SOURI, M.K. Beneficial effects of glycine on growth and leaf nutrient concentrations of coriander (Coriandrum sativum) plants. Journal of Plant Nutrition, p.1-8, 2019. http://dx.doi.org/10.1080/0 1904167.2019.1628985
NAGLAA, M.; KHATTAB, M.; EL-SHENNAWY, O.; MOSTAFA, M. Effect of nitrogen and some antioxidants on tuberose production, Alex. Journal of Agricultural Research, v.56, p.49-63, 2011.

PACHECO,A.C.; CABRAL, C.D.S.; FERMINO, É.S.D.S.; ALEMAN, C.C. Salicylic acid-induced changes to growth, flowering and flavonoids production in marigold plants. Global Journal of Medicinal Plants Research, v.1, n.1, p.95-100, 2013.

PATIL, N.; LALL, B. Effect of presowing treatment with L-ascorbic acid and gibberellic acid on growth and physiological constituents of wheat. Biological Abstracts, v.57, n.34. 1973.

PITTENGER, D.R.; SHAW, D.A.; HODEL, D.R.; HOLT, D.B. Responses of landscape groundcovers to minimum irrigation. Journal of Environmental Horticulture, v.19, p.78-84, 2001.

QURESHI, U.S.; IZHAR, S.; CHUGHTAI, S.; MIR, A.R.; QURESHI, A.R. Efficacy of boron and salicylic acid on quality production of sim carnation (Dianthus caryophyllus). International Journal of Biosciences, v.7, n.1, p.14-21, 2015. http://dx.doi.org/10.12692/ijb/7.1.14-21

RIVAS-SAN VICENTE, M.; PLASENCIA, J. Salicylic acid beyond defense: its role in plant growth and development. Journal of Experimental Botany, v.62, p.3321-3338, 2011. https://doi.org/10.1093/jxb/err031

SARDOEI, A.S.; SHAHDADNEGHAD, M. Response of application Zinc Sulphate and Ascorbic Acid on Gazania (Gazania rigens) Plants. International Journal of Biological Sciences. v.1, n.1, p.54-59, 2014.

SARDOEI, A.S.; SHAHDADNEGHAD, M.; YAZDI, M.R.; GHOLAMSHAHI, S. Growth response of Petunia hybrid to Zinc Sulphate and Salicylic Acid. International Journal of Advanced Biological and Biomedical Research, v.2, n.3, p.622-627, 2014.

SAS, INSTITUTE. SAS user guide and program version 9.0.38. Cary: NC27513, 2002.

SMIRNOFF, N. The function and metabolism of ascorbic acid in plants. Annals of Botany, v.78, p.661-669. 1996.

SOURI, M.K.; BAKHTIARIZADE, M. Biostimulation effects of rosemary essential oil on growth and nutrient uptake of tomato seedlings. Scientia Horticulture, v.243, 472-476, 2019. https://doi.org/10.1016/j. scienta.2018.08.056 
SOURI, M.K.; HATAMIAN, M. Aminochelates in plant nutrition; a review. Journal of Plant Nutrition, v.42, n.1, p.67-78, 2019. https://doi.org/10.1080/01904167.2018.1 549671

SOURI, M.K.; TOHIDLOO, G. Effectiveness of different methods of salicylic acid application on growth characteristics of tomato seedlings under salinity. Chemical and Biological Technologies in Agriculture, v.6, n.1, p.26, 2019. https://doi.org/10.1186/s40538-019-0169-9
TULLIO, M.C.; ARRIGONI, O. Hopes, disillusions and more hopes from vitamin C. Cellular and Molecular Life Sciences, v.61, n.2, p.209-219, 2004. https://doi. org/10.1007/s00018-003-3203-8

ZAMANI, S.; HADAVI, E.; KAZEMI, M.; HEKMATI, J. Effect of some chemical treatments on keeping quality and vase life of Chrysanthemum cut flowers. World Applied Sciences Journal, v.12, n.11, 1962-1966, 2011. 